\title{
Determinants of profitability of black soldier fly farming enterprise in Kenya
}

\author{
K.V. Mutuku ${ }^{1 *}$ (D) A.W. Mukhebi ${ }^{1}$, M.A. Orinda ${ }^{1}$ and C.M. Tanga ${ }^{2}$ \\ ${ }^{1}$ Department of Agricultural Economics \& Agribusiness Management, Jaramogi Oginga Odinga University of Science and \\ Technology, P.O. Box 210-40601, Bondo, Kenya; ${ }^{2}$ International Centre of Insect Physiology and Ecology (icipe), P.O. Box \\ 30772-00100, Nairobi, Kenya; kmutuku@jooust.ac.ke
}

Received: 16 April 2021 / Accepted: 24 September 2021

(c) 2021 Wageningen Academic Publishers

OPEN ACCESS CC (1) RESEARCH ARTICLE

\begin{abstract}
Black soldier fly (BSF) farming is emerging as a new farm enterprise in Kenya poised to provide high-quality and affordable alternative protein sources for animal feed production. Consequently, commercialisation and adoption require farmers to understand if the enterprise is economically viable. This study sought to assess the determinants of profitability of the BSF farm enterprise. A census survey was conducted whereby 34 well-established smallholder BSF farmers were interviewed. A double log regression analysis on the determinants of profitability of the BSF farm enterprise was done. The results revealed that $93.6 \%$ of the variation in enterprise gross margin was explained by the independent variables. Feed and household size contributed positively and significantly to the enterprise gross margin. Labour was significantly and negatively correlated to the enterprise gross margin. Farm size, gender, level of education, and age of the farmer did not significantly influence the gross margin of the enterprise. Furthermore, the survey showed that a $1 \%$ increase in man-hours spent in the BSF farming enterprise would result in a $0.34 \%$ reduction in the gross margin while a $1 \%$ increase in the usage of the rearing substrate would lead to a $1.38 \%$ increase in the gross margin. There is a need for farmers to reduce the man-hours spent in the BSF farms but at the same time increase significantly the utilisation of more rearing substrate to improve their profitability. However, a longterm socio-economic impact assessment on the BSF farming enterprise would be valuable to attract investors and interest in the insect production sector for animal feed.
\end{abstract}

Keywords: black soldier fly, gross margin, enterprise, profitability

\section{Introduction}

According to UNDESA (2019), 9.8 billion people are envisaged to be inhabiting the continent by the year 2050 . To sustain this fast-growing population, food production must increase (Alexandratos and Bruinsma, 2012). Foley et al. (2011) noted that this increased demand for food raises concerns over the environmental impact of the expansion of land under agriculture on a global scale. Sachs (2015) further highlighted that conventional agricultural production has been a significant contributor to greenhouse gases and this has been linked to climate change on a global scale with evident impacts. Consequently, alternative sources of food which are cognisant of the environmental impact must be identified.
Edible insects production is environmentally friendly and cost-effective than either keeping livestock or growing crops, which is becoming unsustainable due to dwindling land and water scarcity imposed by climate change (Bosch $e t$ al., 2019; Van Huis, 2015; Wang and Shelomi, 2017). Edible insects production enterprise is a low-cost technology with a reduced ecological footprint (limited greenhouse gas emission), and less water and land requirement for production (Lensvelt and Steenbekkers, 2014). Notably, edible insects have emerged as sustainable alternative sources of high-quality animal proteins and fat that can be used by humans or for livestock feeding (Purschke et al., 2017). They have been incorporated as alternative ingredients in the making of animal feeds. This has had a positive contribution to farmers by reducing the costs of feeding and thus increasing their profitability levels (Anankware et al., 2018). Despite these advantages, insect 
production has its delimitations. For instance, the quality of output is highly dependent on the quality of the inputs. Further, many countries, especially developing countries are lacking a fully equipped regulatory framework that can solve any issues that may arise when enabling these innovations in the market (Siripan, 2019).

Black soldier fly (BSF), Hermetia illucens larva, has received a lot of research attention as an alternative protein ingredient in animal feed (Dabbou et al., 2018; Nyakeri et al., 2017; Schiavone et al., 2018; Wang and Shelomi, 2017). BSF continues to gain popularity because of its ability to grow effectively on a large variety of waste streams (Hoc et al., 2019; Van Huis et al., 2020). The larvae are outstanding candidates for various applications ranging from organic material and waste management, integration in fish, poultry, and pigs' feeds (Bosch et al., 2019; Nyakeri et al., 2017; Vernooij et al., 2019).

Developing countries, Kenya included have a dire need for animal protein. Consequently, the few available animal proteins are not available to the reach of many due to the high prices (Nyakeri et al., 2017). As a result, insufficient protein consumption is a persistent problem. However, there is potential to increase the economic status of populations across Africa since the rearing and harvesting of edible insects can be a source of livelihood to the poorer segment of the society (Diener et al., 2009). This will increase availability and access to highly nutritious protein while being conscious of environmental preservation through biodiversity promotion (Schönfeldt and Hall, 2012).

Evidently, in this dilemma, Hoc et al. (2019) noted that BSF could be a remedy. BSF is advantageous over other insects due to its significant role in converting waste to food while at the same time reducing pollution and costs (Bosch et al., 2019; Salomone et al., 2017; Surendra et al., 2016; Wang and Shelomi, 2017). On the same note, there is a very attractive market for dry BSF larvae which has been growing globally (Diener et al., 2009). This baseline informs the promotion of BSF as a farm enterprise in Kenya. There is massive interest in farming BSF in the country. However, to produce BSF sufficiently to meet the demand of the animal feed industries, uptake needs to be increased drastically. Farmers have to be encouraged to adopt this new enterprise, through the dissemination of information on economic viability and determinants of its profitability. To realise this, there is a need to explore its production as a commercial farm enterprise. Thus the objective of this study was to assess the determinants of profitability of the BSF farm enterprise.

\section{Materials and methods}

\section{Description of the study area}

This study was conducted in the counties of Nairobi, Kiambu, Murang'a, Kajiado, Machakos, and Nakuru in Kenya (Figure 1). These counties were purposively selected using the existing platform of farmers trained and supported by the International Centre of Insect Physiology and Ecology (icipe) Additionally, these counties experience climatic conditions that are favorable for BSF farming. These regions experience a temperature range of 14 to $28^{\circ} \mathrm{C}$ (Alternative, 2021). In cases where the conditions were averse, for instance in the counties of Kiambu, Murang'a, and Nairobi where temperatures go below $23{ }^{\circ} \mathrm{C}$ during the cold season, farmers made improvements using light-emitting diodes light sources. This helped improve the temperatures to optimal conditions and maintaining light intensity in times when there is not enough sunlight since the flies are attracted to light and prefer mating under the light. The farmers in the study area were smallholder farmers and their production activities were undertaken manually.

BSF farmers are still relatively few in the country. The sample frame (34) for this study was composed of a census of active smallholder BSF farmers in the respective survey sites. A census approach was more appropriate, particularly due to the small population involved, to minimise errors and provide data on all possible individuals in the population (Chia et al., 2020; Israel, 1992). This allows us to study every unit in the population, to ensure accuracy. In this study, in-depth interviews were conducted since the respondents were few. Though this type of data collection is timeconsuming, the respondents were informed in advance and given a schedule on a day that was appropriate or convenient for them, to allow for sufficient timing before the interviews. Further, the interviews provided an opportunity to generate more insightful responses. The respondents were also allowed to validate the data they had provided to avoid bias.

\section{Statistical analysis}

All statistical analyses were performed using SPSS software version 20 (IBM, Armonk, NY, USA). Pearson correlation was done to measure the strength and direction between the independent and dependent variables. Multicollinearity was checked through the use of variance inflation factor values. Descriptive characteristics such as percentages were used to analyse BSF farmers' socio-economic characteristics. The determinants of profitability of the BSF farm enterprise were analysed using a double log regression model. The model enabled the transformation of variables that were highly skewed to more appropriately normal variables making them fit for analysis. It further enabled the handling of the non-linear relationship between gender and the gross 


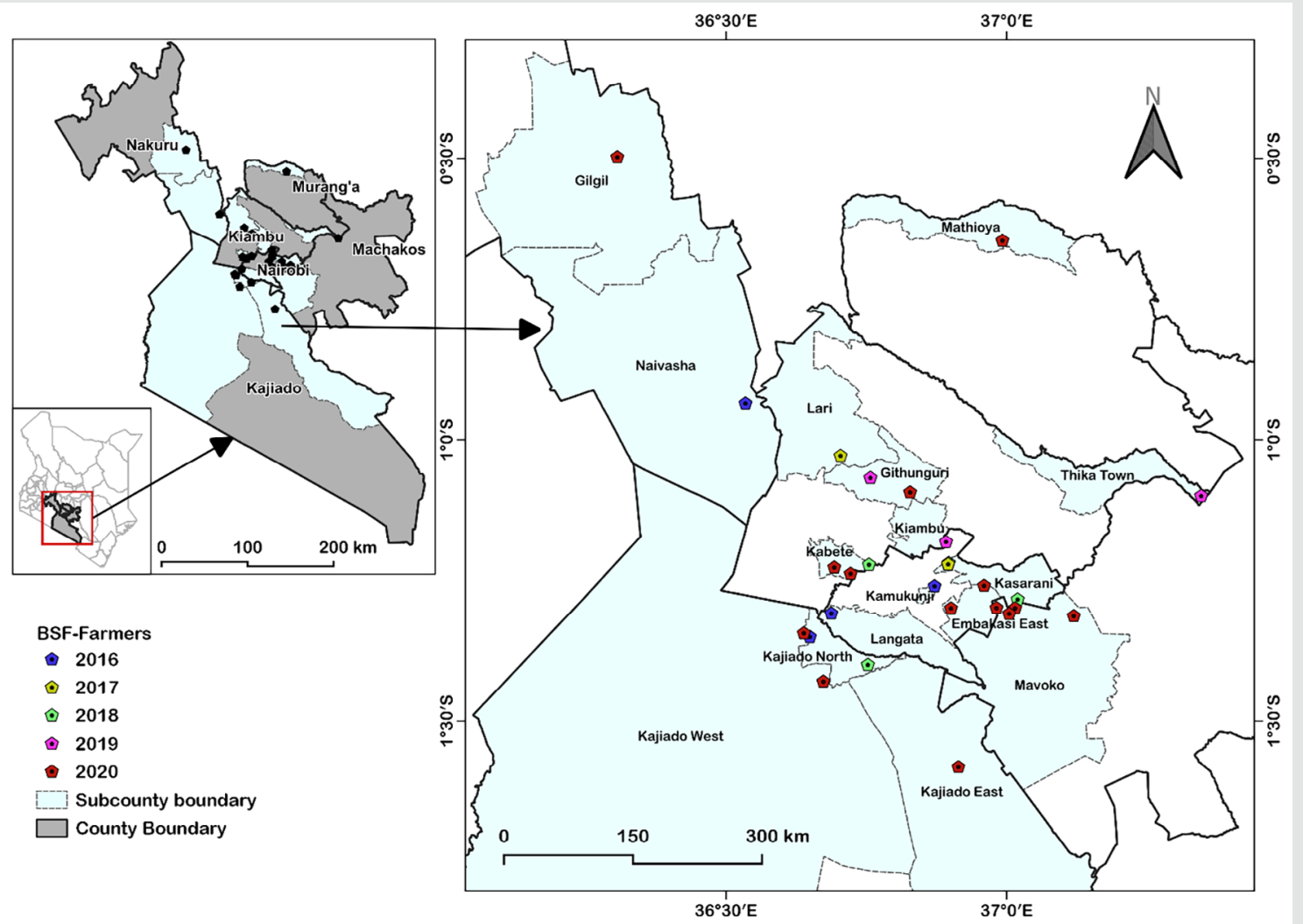

Figure 1. Map illustrating the distribution of black soldier farm enterprises in the study sites according to the year of establishment.

margin. Furthermore, the study assumes that the error term is normally distributed thus the choice of the model. Notably, for gender that is a dummy variable, during data collection it was coded as 0 (male) and 1 (female). However, to enable analysis using the double log regression model, this was recoded into 1 (male) and 2 (female).

The model used several explanatory variables to predict the outcome of the response variable i.e. BSF enterprise gross margin. The double log function was specified as:

$\log Y=\beta_{0}+\beta 1 \log X_{1}+\beta 2 \log X_{2}+\beta 3 \log X_{3}+\beta 4 \log$ $X_{4}+\beta 5 \log X_{5}+\beta 6 \log X_{6}+\beta 7 \log X_{7}+\beta 8$ $\log X_{8}+\varepsilon$

where:

$\mathrm{Y}=$ Gross margin per acre of the BSF enterprise (KES)

$\mathrm{X}_{1}=$ Substrate purchased per acre

$\mathrm{X}_{2}=$ Cost of labor in man-hours per acre

$\mathrm{X}_{3}=$ Farm size (total area under BSF production in acres)

$\mathrm{X}_{4}=$ Household size

$\mathrm{X}_{5}=$ Level of education

$\mathrm{X}_{6}=$ Age of the farmer

$\mathrm{X}_{7}=$ Experience

$\mathrm{X}_{8}=$ Gender

$\varepsilon=$ Error term $\beta_{0}=$ Constant term (the intercept)

$\beta_{\text {is }}=$ Slope parameters

$\log =$ Common logarithm

\section{Results}

\section{Demographic characteristics of the black soldier fly farmers}

The demographic characteristics of BSF farmers are shown in Table 1 . Over $70.6 \%$ of the farmers interviewed were males and 29.4\% females. Among these farmers, 79.4\% had either college or university education. Households with 3-5 members were the majority representing $67.6 \%$. It was observed that $64.7 \%$ of the respondents had been practicing BSF farming for less than 2 years. $97.1 \%$ of the farmers had farm sizes below 1 acre.

\section{Determinants of black soldier fly farm enterprise profitability}

The model results indicate that $93.6 \%$ of the variance in BSF enterprise gross margin was explained by the predictor variables (Table 2). There was a strong positive correlation between the dependent (BSF farm enterprise gross margin) and the independent variables (substrate; labor; farm size; 
household size; level of education; the age of the farmer; experience; gender $)(\mathrm{F}=57.316, \mathrm{df}=31, P \leq 0.0001)$.

Substrate and household size had a significantly positive relationship with the gross margin. Labor had a significantly negative relationship with the gross margin. Farm size, the

Table 1. Demographic characteristics of the black soldier fly farmers.

$\begin{array}{lcc}\text { Characteristics } & \text { Number of farmers } & \text { Percentage (\%) } \\ \text { Gender } & & \\ \text { Male } & 24 & 70.6 \\ \text { Female } & 10 & 29.4 \\ \text { Age } & & \\ \text { 18-35 } & 17 & 50 \\ \text { 36-60 } & 17 & 50 \\ \text { Level of education } & & \\ \text { Primary } & 1 & 2.9 \\ \text { Secondary } & 6 & 17.6 \\ \text { College/university } & 27 & 79.4 \\ \text { Household size } & & \\ \text { 0-2 } & 1 & 2.9 \\ \text { 3-5 } & 23 & 67.6 \\ \text { 6-8 } & 9 & 26.5 \\ \text { Above 9 } & 1 & 2.9 \\ \text { Farming years } & & \\ \text { Below 2 } & 22 & 64.7 \\ \text { 3-5 } & 12 & 35.3 \\ \text { Farm size } & & \\ \text { 0-1 acres } & 33 & 2.9 \\ \text { 1-2 acres } & 1 & \\ & & \end{array}$

level of education, age, experience, and gender did not vary significantly. There was a significant relationship between BSF enterprise gross margin and the independent variables.

The Empirical model is:

$\log Y=1.124+1.376 \log X_{1}-0.338 \log X_{2}-0.074 \log$ $\mathrm{X}_{3}+0.061 \log \mathrm{X}_{4}-0.640 \log \mathrm{X}_{5}-0.018 \log \mathrm{X}_{6}+0.171$ $\log X_{7}-0.031 \log X_{8}+0.824$

\section{Discussion}

The amount of rearing substrate had a significantly positive relationship with the enterprise gross margin. The positive coefficient of substrate implies that an additional kilogram of the substrate in the production system would result in increased marginal returns at an increasing rate. These findings contravene reports by various authors (Altahat et al., 2012; Esiobu et al., 2014; Siyaya and Masuku, 2013; Ukwuaba and Inoni, 2012), who demonstrated that the input used for feeding had a significant but negative relationship to the profit margin of farmers. They attributed this to the high cost of feeds which was not the case in the current study. In BSF farming, the quantity and quality of substrate have been shown to significantly affect larvae growth performance and quality (Vuong, 2020). As per the findings of this study, a $1 \%$ increase in the usage of the rearing substrate resulted in a $1.38 \%$ increase in the gross margin. It was observed that the cost of the substrate was very minimal, in some instances, the farmers obtained the substrate for free with the only cost associated with it being labor and transportation which were consequentially minimal. This probably explains why an extra shilling spent by farmers on the substrate as an input resulted in

Table 2. Double log regression estimates for determinants of profitability of the black soldier fly farm enterprise. ${ }^{1}$

\begin{tabular}{|c|c|c|c|c|c|}
\hline \multicolumn{2}{|c|}{ Model } & \multicolumn{2}{|c|}{ Unstandardised coefficients } & \multirow[t]{2}{*}{$t$-value } & \multirow[t]{2}{*}{$P$-value } \\
\hline & & $\beta$ & SE & & \\
\hline \multirow[t]{11}{*}{1} & (Constant) & 1.124 & 0.824 & 1.364 & 0.186 \\
\hline & Log $X_{1}$ (substrate) & 1.376 & 0.099 & 13.849 & $0.000^{\star \star *}$ \\
\hline & $\log X_{2}$ (labour) & -0.338 & 0.095 & -3.557 & $0.002^{* *}$ \\
\hline & $\log X_{3}$ (farm size) & -0.074 & 0.067 & -1.106 & $0.280^{\mathrm{NS}}$ \\
\hline & Log $X_{4}$ (household size) & 0.061 & 0.024 & 2.537 & $0.018^{*}$ \\
\hline & $\log X_{5}$ (level of education) & -0.640 & 0.521 & -1.227 & $0.232^{\mathrm{NS}}$ \\
\hline & $\log X_{6}$ (age of the farmer) & -0.018 & 0.358 & -0.051 & $0.960^{\mathrm{NS}}$ \\
\hline & $\log X_{7}$ (experience) & 0.171 & 0.168 & 1.018 & $0.319^{\mathrm{NS}}$ \\
\hline & $\log X_{8}$ (gender) & -0.031 & 0.086 & -0.364 & $0.719^{\mathrm{NS}}$ \\
\hline & $\mathrm{R}^{2}$ & 0.952 & & F-statistic & 57.316 \\
\hline & Adjusted $\mathrm{R}^{2}$ & 0.936 & & Prob (F-statistic) & 0.000 \\
\hline
\end{tabular}

\footnotetext{
${ }^{1} \mathrm{NS}=$ not significant; ${ }^{*}=P \leq 0.05 ;{ }^{* *}=P \leq 0.01 ;{ }^{* * *}=P \leq 0.001 ; \beta=$ regression coefficient; $\mathrm{SE}=$ standard error; dependent variable = gross margin; Predictors $=$
} (constant), substrate, labour, farm size, household size, level of education, age of the farmer, experience and gender. 
increasingly marginal returns. The findings further highlight that the optimal capacity utilisation for the substrate hasn't been reached and that there is still potential for farmers to increase the output and consequentially their marginal profit by increasing its usage in the production system.

Labor had a significantly negative relationship with the enterprise gross margin. These results are in consonance with (Altahat et al., 2012; Ehinmowo et al., 2015; Ezeano and Ohaemesi, 2019; Itam et al., 2014), who observed a significantly negative relationship between labor and gross profit. These findings contradict Ogisi et al. (2013) who demonstrated that labor had a significantly positive effect on farming output. The negative slope of labor implies that the opportunity cost of input in the enterprise is too high and that more units are being spent without commensurate return. In this study, a $1 \%$ increase in man-hours spent in the BSF farming enterprise resulted in a $0.34 \%$ reduction in the gross margin. It is presumed that more man-hours put into the enterprise without proper utilisation are resulting in diminishing marginal contribution of labor. This limits output and thus possible consequent reduction in farmers' marginal profit as per Onoja et al. (2012). According to the model results, the farmers in the study region were in their third stage of the production function with regards to the use of labor as input (Onoja et al., 2012). However, further studies on long-term effect of labor on the marginal profit of BSF farmers would be crucial.

Household size had a significantly positive effect on the enterprise gross margin. These results are in tandem with those of previous studies (Ehinmowo et al., 2015; Lungu, 2013; Onoja et al., 2012), whereby a positive and significant relationship was observed between household size and output or gross margin. Labor is a very common input in BSF production systems for activities such as larvae feeding, harvesting, sieving, and marketing. Most of which are carried out manually. This probably explains why the coefficient of household size was significant and positive influencing profitability. This is obvious because family size is a significant source of cheap labor in many agricultural production systems as noted by Ehinmowo et al. (2015) and Onoja et al. (2012). This implies that more family members involved in production provide cheap labor, thus a more profitable farming system. This is because more family members are allocating their time in production thus reducing the need for hired labor (Onoja et al., 2012), such was the case in this study.

Farm size, gender, level of education, age, and the farming experience did not significantly influence the gross margin of the enterprise. The authors acknowledge that the sample size of this study was small, which is a shortcoming but this was due to the Covid 19 pandemic restrictions that hindered movement as a result of frequent lockdowns. Given that this is an emerging enterprise in the country, further studies are highly recommended with larger sample sizes of farmers.

\section{Conclusions and recommendations}

The findings demonstrated that the substrate, labor, and household size were the main determinants of profitability of the BSF enterprise. As such, there is still potential for farmers to increase the output and consequentially their marginal profit by increasing the amount and quality of substrate used in their production facilities. The family was the primary source of labor thus household size was significant. It was further noted that there was a generous allocation of labor to the enterprise due to its availability. This leads to higher opportunity costs of labor without commensurate return thus a subsequent decline in marginal returns. Farm size, gender, level of education, and age of the farmer did not significantly influence the gross margin of the enterprise. This study recommends long-term socioeconomic impact assessment studies on the BSF farming enterprise to strengthen and promote uptake through the support of investors in the insect production sector.

\section{Acknowledgements}

The authors gratefully acknowledge the contribution of Mr. Makatiani Collins Bulinda from the Social Science and Impact Assessment Unit (SSIAU) at icipe for his technical support in the field as well as the farmers for their willingness to assist in the provision of data for this research. The authors also wish to express their sincere gratitude to the Africa Centre of Excellence in Sustainable Use of Insects as Foods and Feeds (ACE-INSEFOODS), at the Jaramogi Oginga Odinga University of Science and Technology (JOOUST), Bondo, Kenya for providing this scholarship to the student.

Financial support for this research was provided by the Canadian International Development Research Centre (IDRC) and the Australian Centre for International Agricultural Research (ACIAR) (INSFEED - Phase 2: Cultivate Grant No: 108866-001); World Bank; Norwegian Agency for Development Cooperation, the Section for research, innovation, and higher education grant number RAF-3058 KEN-18/0005 (CAP-Africa), Netherlands Organization for Scientific Research, WOTRO Science for Global Development (NWO-WOTRO) (ILIPA - W 08.250.202) and the Rockefeller Foundation (SiPFeed - Grant No: 2018 FOD 009). We also gratefully acknowledge the support of the International Centre of Insect Physiology and Ecology (icipe) core funding provided by the United Kingdom's Foreign, Commonwealth, and Development Office (FCDO); the Swedish International Development Cooperation Agency (Sida); the Swiss Agency for Development and Cooperation (SDC); the Federal Democratic Republic of Ethiopia; and the Government of the Republic of Kenya. The first author, 
Kennedy V. Mutuku, was financially supported by the World Bank through the Africa Center of Excellence in Sustainable Use of Insects as Food and Feeds (INSEFOODS), In-Region Postgraduate Scholarship Programme. The funders had no role in the study design, data collection, and analysis, decision to publish, or preparation of the manuscript. Therefore, the views expressed herein do not necessarily reflect the official opinion of the donors.

\section{Conflict of interest}

The authors declare no conflict of interest.

\section{References}

Alexandratos, N. and Bruinsma, J., 2012. World agriculture towards 2030/2050: the 2012 revision. FAO, Rome, Italy.

Altahat, E., Al-Sharafat, A. and ltarawneh, M., 2012. Factors affecting profitability of layer hens' enterprises. American Journal of Agricultural and Biological Sciences 7: 106-113. https://doi. org/10.3844/ajabssp.2012.106.113

Alternative, A., 2021. Adventure alternative. Available at: https://www. adventurealternative.com/kenya-climate/

Anankware, J., Ayizanga, A., Opoku, O. and Obeng-Ofori, D., 2018. Potential of the black soldier fly (Hermetia illuscens) as a replacement for fish/soybean meal in the diet of broilers. Global Advanced Research Journal of Agricultural Science 7: 272-280.

Bosch, G., Van Zanten, H.H.E., Zamprogna, A., Veenenbos, M., Meijer, N.P., Van der Fels-Klerx, H.J. and Van Loon, J.J.A., 2019. Conversion of organic resources by black soldier fly larvae: legislation, efficiency and environmental impact. Journal of Cleaner Production 222: 355-363. https://doi.org/10.1016/j.jclepro.2019.02.270

Chia, S.Y., Macharia, J., Diiro, G.M., Kassie, M., Ekesi, S., Van Loon, J.J. and Tanga, C.M., 2020. Smallholder farmers' knowledge and willingness to pay for insect-based feeds in Kenya. PLoS ONE 15: e0230552. https://doi.org/10.1371/journal.pone.0230552

Dabbou, S., Gai, F., Biasato, I., Capucchio, M.T., Biasibetti, E., Dezzutto, D. and Schiavone, A., 2018. Black soldier fly defatted meal as a dietary protein source for broiler chickens: effects on growth performance, blood traits, gut morphology and histological features. Journal of Animal Science and Biotechnology 9: 49. https://doi. org/10.1186/s40104-018-0266-9

Diener, S., Zurbrügg, C. and Tockner, K., 2009. Conversion of organic material by black soldier fly larvae: establishing optimal feeding rates. Waste Management and Research 27: 603-610. https://doi. org/10.1177/0734242X09103838

Ehinmowo, O.O., Afolabi, J.A. and Fatuase, A.I., 2015. Determinants of profitability among small scale cassava processors in South Western Nigeria. Russian Journal of Agricultural and Socio-Economic Sciences 37: 23-28.

Esiobu, N.S., Onubuogu, G.C. and Okoli, V.B.N., 2014. Determinants of income from poultry egg production in Imo State, Nigeria: an econometric model approach. Global Advanced Research Journal of Agricultural Science 3: 186-199.
Ezeano, C.I. and Ohaemesi, C.F., 2019. Analysis of profitability and its determinants in small scale turkey production in Anambra State, Nigeria. International Journal of Science and Research 8: 455-460.

Foley, J.A., Ramankutty, N., Brauman, K.A., Cassidy, E.S., Gerber, J.S., Johnston, M. and Zaks, D.P., 2011. Solutions for a cultivated planet. Nature 478: 337-342. https://doi.org/10.1038/nature10452

Hoc, B., Noël, G., Carpentier, J., Francis, F. and Megido, R., 2019. Optimization of black soldier fly (Hermetia illucens) artificial reproduction. PLoS ONE 14: e0216160. https://doi.org/10.1371/ journal.pone.0216160

Israel, G.D., 1992. Determining sample size. University of Florida Cooperative Extension Service, Institute of Food and Agriculture Sciences, EDIS, Florida, USA.

Itam, K.O., Ajah, E.A. and Agbachom, E.E., 2014. Analysis of determinants of cassava production and profitability in Akpabuyo Local Government Area of Cross River State, Nigeria. International Business Research 7: 128. https://doi.org/10.5539/ibr.v7n12p128

Lensvelt, E.J. and Steenbekkers, L.P.A., 2014. Exploring consumer acceptance of entomophagy: a survey and experiment in Australia and the Netherlands. Ecology of Food and Nutrition 53: 543-561. https://doi.org/10.1080/03670244.2013.879865

Lungu, C.H., 2013. Factors affecting the profitability of broiler chicken production among small scale farmers in Lusaka. The University of Zambia, Lusaka, Zambia. Available at: http://dspace.unza.zm/ handle/123456789/4557

Nyakeri, E.M., Ogola, H.J., Ayieko, M.A. and Amimo, F.A., 2017. An open system for farming black soldier fly larvae as a source of proteins for small-scale poultry and fish production. Journal of Insects as Food and Feed 3: 51-56. https://doi.org/10.3920/ JIFF2016.0030

Ogisi, O.D., Begho, T. and Alimeke, B.O., 2013. Productivity and profitability of cassava (Manihot esculenta) in Ika south and Ika North East local government areas of Delta state, Nigeria. Journal of Agriculture and Veterinary Science 6: 52-56.

Onoja, A.O., Deedam, N.J. and Achike, A.I., 2012. Profitability and yield determinants in Nigerian cocoa farms: evidence from Ondo State. Journal of Sustainable Development in Africa 14: 172-183.

Purschke, B., Scheibelberger, R., Axmann, S., Adler, A. and Jäger, H., 2017. Impact of substrate contamination with mycotoxins, heavy metals and pesticides on the growth performance and composition of black soldier fly larvae (Hermetia illucens) for use in the feed and food value chain. Food Additives and Contaminants Part A 34: 1410-1420. https://doi.org/10.1080/19440049.2017.1299946

Sachs, J.D., 2015. Why some countries developed while others stayed poor. Columbia University Press, New York, NY, USA, 544 pp. https://doi.org/10.7312/sach17314

Salomone, R., Saija, G., Mondello, G., Giannetto, A., Fasulo, S. and Savastano, D., 2017. Environmental impact of food waste bioconversion by insects: application of life cycle assessment to process using Hermetia illucens. Journal of Cleaner Production 140: 890-905. https://doi.org/10.1016/j.jclepro.2016.06.154

Schiavone, A., Dabbou, S., De Marco, M., Cullere, M., Biasato, I., Biasibetti, E. and Gasco, L., 2018. Black soldier fly larva fat inclusion in finisher broiler chicken diet as an alternative fat source. Animal 12: 2032-2039. https://doi.org/10.1017/S1751731117003743 
Schönfeldt, H.C. and Hall, N.G., 2012. Dietary protein quality and malnutrition in Africa. British Journal of Nutrition 108: S69-S76. https://doi.org/10.1017/s0007114512002553

Siripan, P., 2019. Advantages and disadvantages of insect farming for food. Available at: https://www.asialifestylemagazine.com/ advantages-and-disadvantages-of-insect-farming-for-food/

Siyaya, B.J. and Masuku, M.B., 2013. Determinants of profitability of indigenous chickens in Swaziland. Business and Economic Research 3: 205. http://dx.doi.org/10.5296/ber.v3i2.4346

Surendra, K.C., Olivier, R., Tomberlin, J.K., Jha, R. and Khanal, S.K., 2016. Bioconversion of organic wastes into biodiesel and animal feed via insect farming. Renewable Energy 98: 197-202.

Ukwuaba, S.I. and Inoni, O.E., 2012. Resource-use efficiency in smallholder broiler production in Oshimili North Local Government Area, Delta State. International Journal of Poultry Science 11: 700. https://doi.org/10.3923/ijps.2012.700.705

United Nations Department of Economic and Social Affairs (UNDESA), 2019. World population prospects: the 2017 revision, key findings and advance. UN, New York, NY, USA. Available at: https://www.un.org/development/desa/publications/worldpopulation-prospects-the-2017-revision.html
Van Huis, A., 2015. Edible insects contributing to food security? Agriculture \& Food Security 4: 20. https://doi.org/10.1186/s40066015-0041-5

Van Huis, A., Oonincx, D.G.A.B., Rojo. S. and Tomberlin, J.K., 2020. Insects as feed: house fly or black soldier fly? Journal of Insects as Food and Feed 6: 221-229. https://doi.org/10.3920/JIFF2020.x003

Vernooij, A.G., Veldkamp, T. and Ndambi, A., 2019. Insects for Africa: developing business opportunities for insects in animal feed in Eastern Africa. Wageningen Livestock Research, Wageningen, the Netherlands. https://doi.org/10.18174/470617

Vuong, V., 2020. Development of insect production automation: automated processes for the production of black soldier fly (Hermetia illucens). MSc-thesis, Aalto University, Espoo, Finland. Wang, Y.S. and Shelomi, M., 2017. Review of black soldier fly (Hermetia illucens) as animal feed and human food. Foods 6: 91. https://doi. org/10.3390/foods6100091 
